This article was downloaded by: [130.132.123.28]

On: 30 December 2014, At: 19:47

Publisher: Routledge

Informa Ltd Registered in England and Wales Registered Number: 1072954

Registered office: Mortimer House, 37-41 Mortimer Street, London W1T

3J H, UK

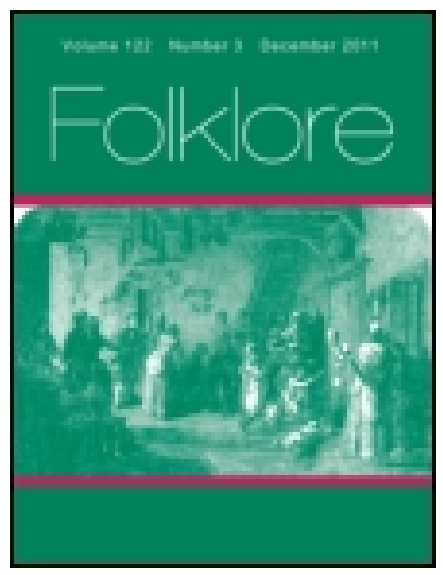

\title{
Folklore
}

Publication details, including instructions for authors and subscription information:

http:// www. tandfonline.com/loi/ rfol20

\section{Cleft Ashes for Infantile Hernia}

E. Sidney Hartland

Published online: 14 Feb 2012.

To cite this article: E. Sidney Hartland (1896) Cleft Ashes for Infantile Hernia, Folklore, 7:3, 303-306, DOI: 10.1080/ 0015587X.1896.9720372

To link to this article: http:// dx. doi. org/ 10.1080/0015587X.1896.9720372

\section{PLEASE SCROLL DOWN FOR ARTICLE}

Taylor \& Francis makes every effort to ensure the accuracy of all the information (the "Content") contained in the publications on our platform. However, Taylor \& Francis, our agents, and our licensors make no representations or warranties whatsoever as to the accuracy, completeness, or suitability for any purpose of the Content. Any opinions and views expressed in this publication are the opinions and views of the authors, and are not the views of or endorsed by Taylor \& Francis. The accuracy of the Content should not be relied upon and should be independently verified with primary sources of information. Taylor and Francis shall not be liable for any losses, actions, claims, proceedings, demands, costs, expenses, damages, and other liabilities whatsoever or howsoever caused arising directly or indirectly in connection with, in relation to or arising out of the use of the Content.

This article may be used for research, teaching, and private study purposes. Any substantial or systematic reproduction, redistribution, reselling, loan, sub-licensing, systematic supply, or distribution in any form to anyone is 
expressly forbidden. Terms $\&$ Conditions of access and use can be found at http://www.tandfonline.com/page/terms-and-conditions 
of the plough on the fresh mould, and now I have told you I sha'n't find no more." Nor did he. $\Lambda$ nd after the tale spread about the village many would have given much never to have interfered; but it was all in vain, for never another shilling did Joe find at the foot of his plough.

Told by Mrs. Brown, of Winterton, Norfolk (awho died last year, 1895, aged 102), to her granddaughter, Afrs. Goodall, who told it to me.

1. H. EMERSON.

\section{Cleft Asiles for Infantile Hernia.}

IHE clcft ash-saplings from a plantation between Needham and llarking, in Suffolk, lately presented to the Society by Mr. Lingwood, were used for the cure of congenital hernia in two children in the year 1894. Three children in all were treated, but the third ash has bcen left standing. Before they wcre cut Mr. Lingwood wrote as follows:

"I found the man Mulley, a hurdlemaker by trade, who performed the operation of passing the child through the cleft stick, was not a believer in the efficacy of the cure, or in any way a quack doctor. I have not been able to sec him myself, but my father had a conversation with him about the matter, and Mullcy said: 'The stick' (which is about the thickness of a stout walkingstick) 'is split up from the ground a few fect and tied at the top, so as to prevent its "running "; the cleft is then held open and the child is passed through three times, each time by a different person. The stick is then securely bound up at short intervals. If it grows together the child will recover.' . . . No care scems to be taken to ensure the growth of the stick beyond that implicd in the binding up by an experienced person. The three sticks that were used last year are now growing in the little plantation, where my father and brother have scen them. ... . Of course, standing in a wood like this is a protection to them, but I can ask Mulley as to protecting them if you like. When next at Necdham I will see them and make a drawing of them for you. I see no reason why I should not cut them if the Society would like one, as all the children are cured(!) I suppose the operator and others are now 
no longer interested in them. It is unnecessary to say the sticks split last year have not yet had time to grow together. Mullcy had not performed the rite for twenty-five years, when he did a boy named Stevens. The boy's father recommended the curc in the present cases."

Mr. Lingwood afterwards kindly took the trouble not only to sketch one of the young trees as it stood (see Plate II.), but also to cut two of them for the Society, and exhibited them at the meeting of the British $\Lambda$ ssociation at Ipswich in September last, when he handed them over to the President. Mr. F. T. Elworthy, who was present, has been good enough to furnish some notcs of a similar case in Somersetshire, including the following extract from the Bath and Wells Diocesan Magazine, December, 1856, p. 178 :

"Extraordinary Superstition in Somerset,- -1 remarkable instance of the extraordinary superstition which still prevails in the rural districts of Somerset has lately come to light at $\Lambda$ thelney. It appears that a child was recently born in that neighbourhood with a physical ailn.ent, and the neighbours persuaded the parents to resort to a very novel method of charm. ing away the complaint. $\Lambda$ sapling ash was split down the centre, and wedges were inserted so as to affo.d an opening sufficient for the child's body to pass through without touching either side of the tree. This having been done, the child was undressed, and, with its face held heavenward, it was d:awn through the sapling in strict accordance with the superstition. Afterwards the child was dressed, and simultaneously the tree was bound up. The belicf of those who took part in this strange ceremony is, that if the tree grows the child will grow out of its bodily ills. The affair took place at the rising of the sun on a recent Sunday morning in the presence of the child's parents, several of the neighbours, and the parish police-constable."

Mr. Elworthy, who had not then seen the foregoing account, wrote, on hearing of the case, to the Spectator. His letter, which appeared on the $5^{\text {th }}$ February, 1887 , was as follows:

"In this parish, some months ago, the wife of a highly respectable farmer presented him with twins, one of which was born with hernia. $\Lambda$ s soon as convenicnt, 'upon a Sunday morning before sunrise, the farmer and his wife, with several neighbours and servants, procecded to a wood on his farm. They then with wedges 
Plate II.

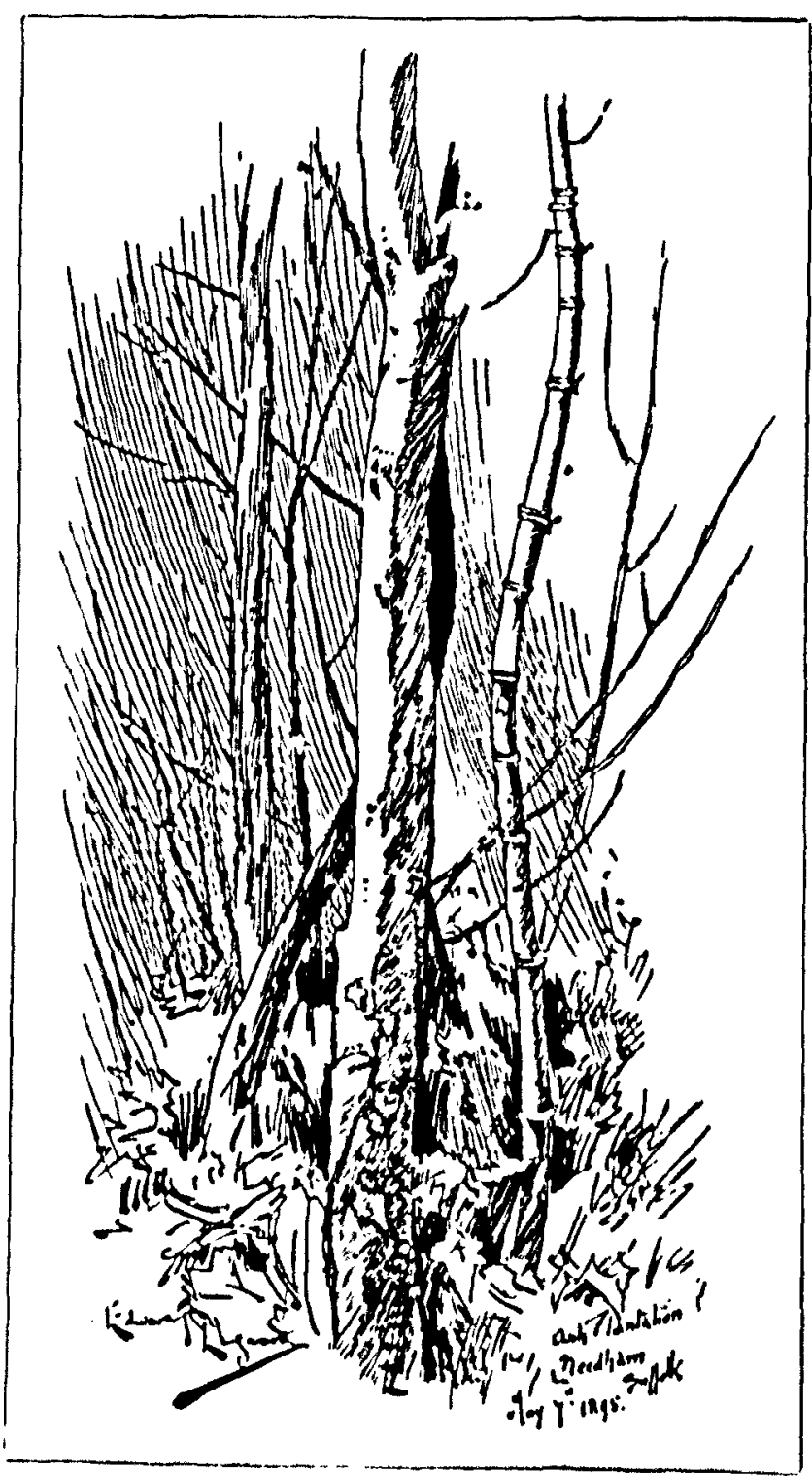

GPLIT ASH-SAPLING USED FOR THE CURE OF INFANTILE HERNIA IN SUFFOLK. 
split a young growing ash-tree, opening the split wide enough to permit the amicted child to pass through. This was done three times with due solemnity, and the tree was restored to its previous condition, barring the split, which was carefully bound up with a hayband. The belief is, that if the sides of the tree unite and grow together, the child will be cured. In this casc, curiosity has removed the hayband, thereby, it is said, preventing the trec from uniting ; but what is the present condition of the child I have becn unable to learn, because the parents have recently left the neighbourhood. I can, however, testify that the ash-tree is now standing unhealed, and with a rent in its stem seven or eight fect long. The belicf in this cure for congenital hernia is an old and wellknown one; but that it should be still practised soberly and solemnly, not by poor ignorant labourers, but by well-to-do, fairly cducated pcople, will perhaps surprise not a few.' "

$\Lambda$ bout four years later MIr. Elworthy procured the tree to be dug up by the roots and deposited in the County Muscum in Taunton Castle. He writes under date 25th September, 1895:

"One of the men who actually split this trce and assisted at the function is now in the service of a neighbour. The mother of the child is well known to me, and is sister of a farmer who is now one of my own tenants. I made some further inquiries of the kecper, and give his own words. "Twas pon a Zunday, you know, Zur, an' avore daylight' (i.e. sunrise). 'THe was a-split proper cast and west. Th' ead' (head) 'o' un was a-put drough fust.' 'Was it done more than once?' ' $O$ ' ees, he was a-draed vore an' back.' 'How many times?' ' $\mathrm{O} /$ he was a-put drough un dree times.' 'Was his head put through first each time?' 'Well, I baint sa-nf 'bout that; I count he was, but I can ax Sam Davis, he help do'd it.' My informant ended confidentially and of his own knowledge : 'The chcel's cver so much better vor't; I count is gwam to make a hard boy arter all.'

"I consider the three times analogous to the three in baptism, while the whole business is manifestly a survival of sun-worship, combined with a re-generation (Sec Evil Eye, pp. 69-70, 106)."

Through Mr. Llworthy's good offices, and by the help of Mir. IV. 13idgood, Curator of the Muscum, I obtained a photographs (reproduced here, Plate III.) of the tree in question, as well as of a model prepared under the direction of 1)r. F. II. Mead, and now also in the Muscum, showing the manner in which the ash is 
opened for the operation. Dr. Mead contributed an interesting paper to the Procecdings of the Somersetshire Archaological and Natural History Society for 1892 (pp. $3^{62}$ seqq.) on the superstition, from which I add the following account of the manner in which the rite is performed in the neighbourhood of Bishop's Lydeard :

"First of all a ground ash-tree must be selected-a maiden ash $-\mathbf{a}$ tree which had grown up without ever having been topped or cut. The tree must be sufficiently large to allow the child to be passed through a longitudinal fissure, formed by partly clearing the stem and holding open the sides of the tree by suitably-applied wedges. $\Lambda$ ligature applied to the upper end of the split would prevent its going too far. The ceremony must take place in the early morning, at the time of the rising of the sun, the prepara. tions necessary being made in the dawn. The child must be first stripped naked and passed from east to west through the fissure, 'between the barks,' as a commonly used expression has it. ' $\Lambda$ virgin must introduce the child, and a boy take him out on the other side. He should be passed feet first. I need not add that cure was assured to the patient, but under certain conditions following. Immediately after the ceremony the wedges were to be removed from the tree, when the natural elasticity of the ash would cause the sides to spring together. Further accurate adjustments must be made by the aid of bark bands and a plastcring of mud or clay on the exterior. Then, if the tree grew together and flourished, as it usually did, only having been split longitudinally, cure would follow; if not, the case would remain unaltered. No prayers or incantations were indicated, and, as far as the mystery was imparted to them, any person might act as director of the ceremony."

May I venture finally to refer to The Legend of Perseus, vol. ii. p. 146 , where further references will be found and a short discussion of the meaning of the rite?

E. Sidney Hartiand.

\section{Berder Corn-Festival.}

As Mr. Gomme informs me that he believes the following interesting extract from the late Sir John Drummond Hay's 